\title{
Impact of Grazing Methods on Forage and Cattle Production 1
}

Joao Vendramini and Lynn Sollenberger ${ }^{2}$

\section{Introduction}

Grassland covers about 10 million acres in Florida and most of this area is grazed by beef cattle. Rapid urbanization is reducing grassland area and may require that beef producers use pastures more efficiently in the future. Grazing method is one management tool that can be used to increase the efficiency of forage and animal production.

\section{Definition}

Grazing methods include rotational or continuous grazing. Rotational grazing is defined as alternating periods of grazing and rest for two or more paddocks in a grazing management unit throughout the grazing season. Continuous grazing is a method of grazing livestock on a specific unit of land where animals have unrestricted and uninterrupted access throughout the grazing season. Rotational grazing has shown advantages over continuous grazing in several measures of forage and beef cattle production. In the following sections, we will describe some of the benefits of rotational grazing for forage production and utilization, animal production, nutrient distribution, and management flexibility. Potential disadvantages will also be mentioned.

Before discussing the advantages and disadvantages of rotational grazing, it is important to note that the most critical grazing management decision is not grazing method but stocking rate. Stocking rate is defined as the amount of land allotted to each animal during the grazing season. If the stocking rate is incorrect, then neither rotational nor continuous grazing will correct the problem. So, the first and most important step in developing a grazing program is to choose the correct stocking rate for your conditions. After that is done, changing grazing method may allow you to fine tune your grazing system.

\section{Forage Production and Utilization}

Production of new growth after grazing depends upon the amount of residual leaf and carbohydrate reserves because they will supply energy for plant growth. Rotational grazing with the correct stocking rate will maintain adequate stubble height and

1. This document is SS-AGR-133, one of a series of the Agronomy Department, Florida Cooperative Extension Service, Institute of Food and Agricultural Sciences, University of Florida. Original publication date January 2007. Visit the EDIS Web Site at http://edis.ifas.ufl.edu.

2. Joao Vendramini, assistant professor, Agronomy Department, Range Cattle Research and Education Center--Ona, FL; Lynn Sollenberger, professor, Agronomy Department, Institute of Food and Agricultural Sciences, University of Florida, Gainesville, FL 32611.

The use of trade names in this publication is solely for the purpose of providing specific information. UF/IFAS does not guarantee or warranty the products named, and references to them in this publication does not signify our approval to the exclusion of other products of suitable composition.

The Institute of Food and Agricultural Sciences (IFAS) is an Equal Opportunity Institution authorized to provide research, educational information and other services only to individuals and institutions that function with non-discrimination with respect to race, creed, color, religion, age, disability, sex, sexual orientation, marital status, national origin, political opinions or affiliations. U.S. Department of Agriculture, Cooperative Extension Service, University of Florida, IFAS, Florida A. \& M. University Cooperative Extension Program, and Boards of County Commissioners Cooperating. Larry Arrington, Dean 
carbohydrate reserves after grazing to maximize forage regrowth. Stewart et al. (2005) verified that bahiagrass (Paspalum notatum) under rotational grazing can produce more forage than under continuous grazing (Table 1). Rotational grazing with $1,3,7$, and 21 days of pasture occupation (21-day rest period between grazings) resulted in greater forage production than pastures that were grazed continuously.

In addition to increased regrowth rates, rotational grazing at the proper stocking rate also aids in pasture persistence by allowing better stubble height control. Controlling target stubble height on rotationally grazed pastures is important, not only to maximize forage regrowth, but also to extend the life span of the pastures. Overgrazing can result in loss of desirable species and an increase in weeds. Target stubble heights for persistence of different warm-season grasses are shown in Table 2.

Results from Florida studies confirm the beneficial effect of rotational grazing on persistence of some grasses. For example, Callie bermudagrass pastures were rotationally or continuously grazed for two years at the same stocking rate (Matthews et al., 1994). Pastures contained $90 \%$ Callie and $10 \%$ common bermudagrass at the beginning of the study. After two years of grazing, Callie percentage was $86 \%$ in rotationally grazed pastures and $62 \%$ in continuously grazed pastures. Callie persisted better under rotational grazing because during the rest period between grazings it grew taller and shaded common, while under continuous grazing the lower-growing common bermudagrass was not shaded nearly as much.

Rotational grazing has the potential to increase grazing efficiency, the percentage of forage produced that animals actually consume. In continuously grazed pastures, a greater proportion of forage is trampled, soiled, and rejected by the animals than in rotationally grazed pastures.

Forage nutritive value is usually not affected by grazing method. In Florida, bahiagrass crude protein, phosphorus, and digestibility were not affected by grazing method or length of the grazing period of rotationally grazed pastures (Dubeux et al., 2005).

\section{Animal Production}

In general, grazing method does not affect average daily gain of beef cattle grazing warm-season grasses; however, the greater forage production and utilization allow greater stocking rates that typically result in greater liveweight gain per unit of land. Matthews et al. (1994) found that stocking rates could be increased by as much as $20 \%$ when bermudagrass pastures were rotationally versus continuously grazed. Average daily gain did not differ between grazing methods and averaged $1.10 \mathrm{lbs} /$ day. However, the increase in stocking rate with similar average daily gains resulted in greater liveweight gains per acre.

\section{Nutrient Distribution}

Grazing cattle retain approximately $20 \%$ of the nutrients ingested from forages and the remaining $80 \%$ is excreted through feces and urine. Feces and urine are important sources of nutrients for forages, mainly for grazing systems with low inputs.

However, in warm climates, the animals tend to concentrate their excreta close to water and shade. Under continuous grazing in warm climates, animals deposited $80 \%$ of the excreta in $30-40 \%$ of the pasture area (Matthews et al., 1996). Rotational grazing increases the uniformity of distribution of the excreta. Dubeux et al. (2005) showed that feces were more uniformly distributed on bahiagrass pastures grazed rotationally than continuously (Figure 1).

At times of increasing fertilizer costs, better distribution of the excreta likely results in improved use of the nutrients by forages and may reduce the amount of commercial fertilizers used in the long run.

\section{Management Flexibility}

Rotational grazing allows producers to make management decisions based on the seasonal variability in forage production and animal requirements. During the months of the year with excessive forage production, rotational grazing allows some pastures to be deferred and used for hay production or stockpiled forage for the winter. In addition, the producer utilizing rotational grazing has the opportunity to better match animal requirements with the pastures ability to supply nutrients. Animals 


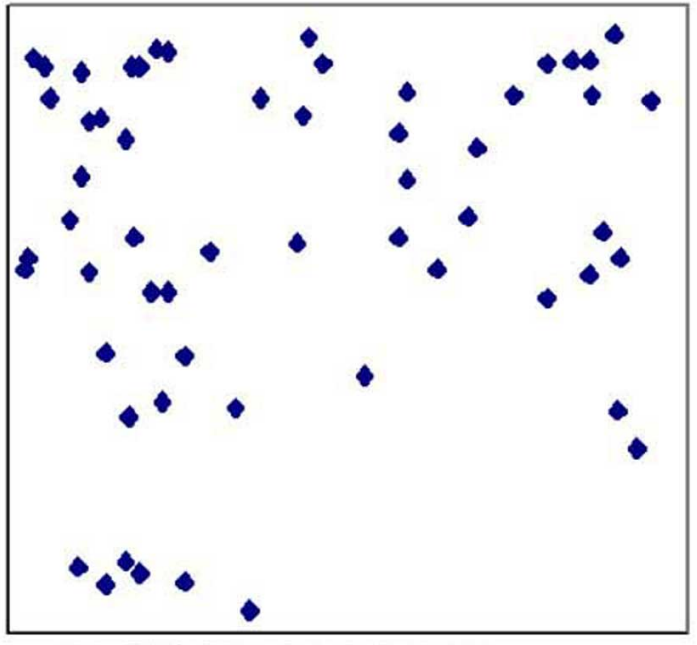

1a. Animals rotated daily

Figure 1.a

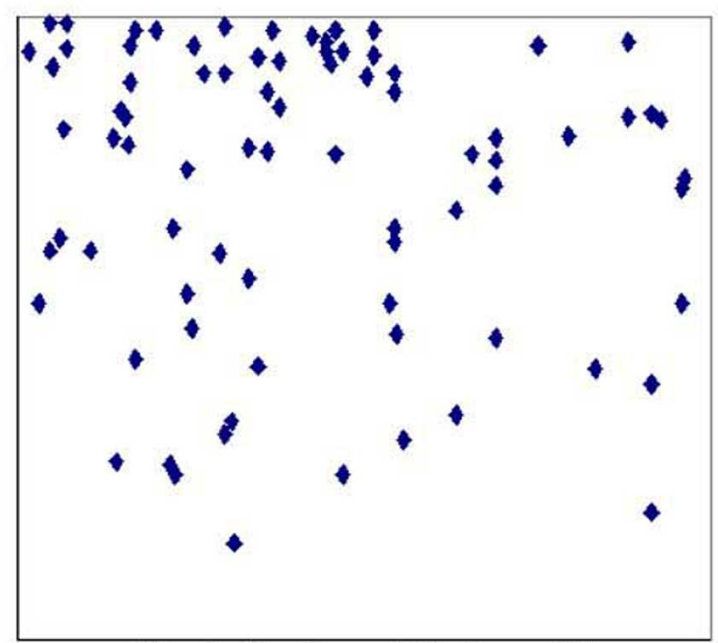

1b. Animals rotated weekly

Figure 1.b

with greater nutrient requirements (i.e., replacement heifers, first calf heifers) can have access to pastures first and graze the greater nutritive value forage. They can be followed by cattle with lower nutrient requirements (i.e., mature cows). Lastly, the periodic handling of the cattle permits managers to inspect the herd frequently so that timely herd management decisions can be made.

\section{Disadvantages of Rotational Grazing}

The main disadvantages of rotational grazing compared with continuous grazing include:

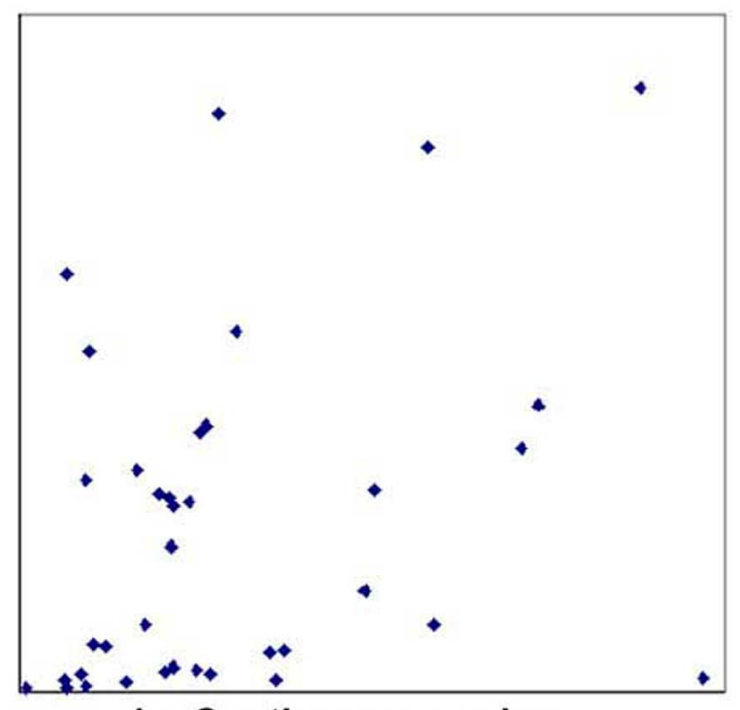

1c. Continuous grazing

Figure 1.c

Figure 1. Feces distribution of beef heifers grazing bahiagrass pastures using different grazing methods at equal stocking rates. Dots represent feces events during 24-hour periods. Resting period for rotational grazing was 21 days. Adapted from Dubeux et al. (2006).

- Initial investment on fences, water, and feed bunks;

- Labor availability to move the animals; and

- More management decisions.

\section{Conclusions}

No single grazing management program will be appropriate for all forages in all environments.

Because of the likelihood of greater forage production and pasture persistence, rotational grazing has potential to increase animal production on beef cattle operations in Florida. The choice of grazing method will depend on the characteristics of a particular beef cattle enterprise including the forage being grazed, the stocking rate used, and the economics of production. In general, rotational grazing will be most needed when stocking rates are high or the forage being grazed requires more careful management for long-term survival (e.g., stargrass, bermudagrass and limpograss). 


\section{References}

Dubeux, J.C.B., Jr., R.L. Stewart, Jr., L.E.

Sollenberger, J.M.B. Vendramini, and S.M.

Interrante. 2006. Spatial heterogeneity of

herbage response to management intensity in

continuously stocked Pensacola bahiagrass

pastures. Agron. J. 98:1453-1459.

Matthews, B.W., L.E. Sollenberger, and C.

Staples. 1994. Dairy heifer and bermudagrass

pasture responses to rotational and continuous

stocking. J. Dairy Sci. 77:244-252

Matthews, B.W., L.E. Sollenberger, and J.P.

Tritschler II. 1996. Grazing systems and spatial

distribution of nutrients in pastures - soil

considerations. p. 213-229. In R.E. Joost and

C.A. Roberts (ed.) Nutrient cycling in forage

systems. PPI/FAR, Columbia, MO.

Mislevy, P. 2002. Forage alternatives for Florida

cattle. p. 79-86. In: $51^{\text {st }}$ Annual Beef Cattle Short

Course Proceedings. University of Florida,

Gainesville, FL.

Stewart, R.L., Jr., J.C.B. Dubeux, Jr., L.E.

Sollenberger, J.M.B. Vendramini, and S.M.

Interrante. 2005. Stocking method affects plant

responses of Pensacola bahiagrass pastures.

Forage \& Grazinglands doi:

10.1094/FG-2005-1028-01-RS. 
Table 1. Forage production on rotationally grazed pastures with different grazing periods (rest period of 21 days for all) and under continuous grazing during 2001-2003. Adapted from Stewart et al. (2005)

\begin{tabular}{||c|c||}
\hline Treatment & $\begin{array}{c}\text { Forage Production } \\
\text { (lb of DM per acre per day) }\end{array}$ \\
\hline Rotational & 58 \\
\hline 1 day & 61 \\
\hline 3 days & 64 \\
\hline 7 days & 67 \\
\hline 21 days & 37 \\
\hline & \\
\hline Continuous & \\
\hline \hline
\end{tabular}

Table 2. Target stubble height for persistence of rotationally grazed warm-season grasses in Florida. Adapted from Mislevy, 2002.

\begin{tabular}{||c|c||}
\hline \hline Species & Target stubble height (inches) \\
\hline Bahiagrass & 2 \\
\hline Bermudagrass & $3-4$ \\
\hline Stargrass & $6-8$ \\
\hline Limpograss & $8-10$ \\
\hline \hline
\end{tabular}

